\title{
Induction of infectious pancreatic necrosis (IPN) in Atlantic salmon Salmo salar and brook trout Salvelinus fontinalis by bath challenge of fry with infectious pancreatic necrosis virus (IPNV) serotype Sp
}

\author{
Torunn Taksdal $^{1, *}$, Kristin Stangeland $^{1}$, Birgit H. Dannevig ${ }^{1,2}$ \\ 'Central Veterinary Laboratory, PO Box 8156 Dep., N-0033 Oslo, Norway \\ ${ }^{2}$ Department of Morphology, Genetics and Aquatic Biology, Norwegian College of Veterinary Medicine, \\ PO Box 8146 Dep., N-0033 Oslo, Norway
}

\begin{abstract}
Thirteen week old Atlantic salmon Salmo salar fry and 15 wk old brook trout Salvelinus fontinalis with average weights of 0.19 and $0.17 \mathrm{~g}$, respectively, were bath challenged with infectious pancreatic necrosis virus (IPNV), serotype Sp, N1 strain. The virus had been isolated from a clinica] outbreak of infectious pancreatic necrosis (IPN) in Atlantic salmon parr. Cell culture supernatant after a first passage of virus was used as the infective material. Approximately 400 fry of each species were divided into 2 parallel tanks with challenged fish and 2 parallel tanks with non-challenged fish. At $69 \mathrm{~d}$ after challenge, cumulative mortalities of Atlantic salmon were 76 and $82 \%$ for the challenged groups and 6 and $15 \%$ for the non-challenged groups. The corresponding values for brook trout were 42 and $43 \%$ for the challenged groups and 8 and $10 \%$ for the non-challenged groups. The onset of mortality in challenged Atlantic salmon was delayed compared with the onset in brook trout. IPNV was reisolated from the fry of all challenged groups. Histological examination of sampled moribund fish showed hepatic degeneration or necrosis and exocrine pancreatic necrosis in fry from all challenged groups. The presence of IPNV in the lesions was demonstrated immunohistochemically. Virological, histological and immunohistochemical examinations of fry sampled prior to challenge and of non-challenged fry gave negative results. This study represents, to our knowledge, the first report of an experimental induction of clinical IPN in Atlantic salmon fry.
\end{abstract}

KEY WORDS: Infectious pancreatic necrosis - Atlantic salmon $\cdot$ Brook trout

\section{INTRODUCTION}

Infectious pancreatic necrosis (IPN) is a contagious fish disease caused by an aquatic birnavirus, infectious pancreatic necrosis virus (IPNV). The virus was isolated for the first time in 1957 (Wolf 1988). It is widespread in the aquatic environment and causes disease in several fish species (McKnight \& Roberts 1976, Sano 1976, Ahne 1980, Sorimachi \& Hara 1985, Castric et al. 1987, Biering et al. 1994).

•E-mail: torunn.taksdal@vetinst.no
In Norway, IPNV was isolated for the first time in 1975 from rainbow trout Oncorhynchus mykiss (Hastein \& Krogsrud 1976) and the first outbreak of IPN in Atlantic salmon Salmo salar was reported in 1985 (Krogsrud et al. 1989). Since 1989, the incidence of the disease has increased considerably. IPN is now considered a significant economic problem affecting farmed Atlantic salmon both in fresh water and in sea water (Jarp et al. 1995, State Veterinary Laboratory, Trondheim 1994, Taksdal et al. 1995) as well as farmed Atlantic halibut Hippoglossus hippoglossus fry (Biering et al. 1994). 
Several studies on experimental challenge of salmonids with IPNV have been published. Most studies have described the use of brook trout Salvelinus fontinalis or rainbow trout exposed to American or European isolates of IPNV (Wolf \& Quimby 1969, Frantsi \& Savan 1971, Elazhary et al. 1976, Swanson \& Gillespie 1981, Swanson et al. 1982, Bootland et al. 1986, McAllister \& Owens 1986, Dorson et al. 1992, McAllister \& Owens 1995). Few studies with Atlantic salmon have been published. Swanson \& Gillespie (1979) exposed Atlantic salmon fry and yearlings to IPNV serotype VR 299, which resulted in a subclinical infection only. In a review of IPNV, Dorson (1982) stated that Atlantic salmon are considered to be refractory to clinical IPN. Smail et al. (1986) found that IPNV serotype $\mathrm{Sp}$ caused mortality in Atlantic salmon sacfry, but not in feeding fry and parr

Studies of IPN in Atlantic salmon are, at present, hampered due to a lack of experimental challenge models. Various experiments in Norway have failed to induce IPN in experimentally challenged Atlantic salmon fry, parr and smolt. Experimental models for the induction of IPN in Atlantic salmon are important for further studies of pathogenesis, vaccination experiments and for selection of resistant salmon strains for breeding purposes.

The aim of the present study was to attempt the experimental induction of clinical IPN in Atlantic salmon fry. As brook trout have been reported to be the most susceptible salmonid species (Silim et al. 1982, Shankar \& Yamamoto 1994), this species was included as a positive control. Fry were used because only young salmonids less than 3 to 5 mo of age have been reported to develop IPN in experimental studies (Frantsi \& Savan 1971, Dorson \& Torchy 1981, McAllister \& Owens 1986).

\section{MATERIALS AND METHODS}

Fish. Fry were obtained from 2 hatcheries in the south of Norway that rear Atlantic salmon and brook trout, respectively. Atlantic salmon fry originated from fish caught in the wild, and were reared from a mixture of eggs from 5 female salmon fertilised with milt from 4 male fish. Spawning was early in November 1994 and hatching was finished in mid-February, 13 wk before challenge. The onset of feeding was in early May, $17 \mathrm{~d}$ before experimental infection with IPNV. In November and December 1994 water temperature was 5.0 to $6.4^{\circ} \mathrm{C}$ i from January until first feeding, 2.5 to $3.8^{\circ} \mathrm{C}$; the temperature then increased to $10.4^{\circ} \mathrm{C}$ at the onset of feeding. It was estimated that the Atlantic salmon fry had experienced 410 degrees $\times$ days from hatching to challenge. The fry were of unitorm size and the average weight was $0.19 \mathrm{~g}$ at challenge.
Brook trout fry also originated from wild fish which had been spawned in late October 1994. Hatching occurred in late January 1995, $15 \mathrm{wk}$ prior to challenge. Feeding started early in May, almost 3 wh before challenge. The water temperature was approximately $5^{\circ} \mathrm{C}$ during the whole period. It was estimated that the brook trout had experienced 560 degrees $x$ days from hatching to challenge. The average weight was $0.17 \mathrm{~g}$ at challenge.

Both hatcheries have been under regular veterinary health surveillance since 1990 . No outbreak of clinical IPN has ever been registered at these locations.

Five hundred fry of each species arrived at the aquarium of the Central Veterinary Laboratory/Norwegian College of Veterinary Medicine $1 \mathrm{wk}$ before challenge. Fish were held in $60 \times 60 \mathrm{~cm}$ tanks with $22 \mathrm{~cm}$ water depth and supplied with a mixture of well water $(30 \%)$ and dechlorinated public water $(70 \%)$ at a flow rate of $0.51 \mathrm{~min}^{-1}$. The water temperature was 8 to $10^{\circ} \mathrm{C}$ and light was constant during the experiment. Feeding was performed 3 to 5 times a day with the same commercial feed that was used in the hatcheries. Fish density was approximately $1.2 \mathrm{~g} \mathrm{l}^{-1}$ of water before challenge and $0.3 \mathrm{~g} \mathrm{l}^{-1}$ after challenge, increasing to approximately $0.8 \mathrm{~g}^{-1}$ in the control tanks during the study.

Cell culture. Bluegill sunfish cells (BF-2, ATTC CCL 91.) were used for the propagation, detection and quantitation of virus. The cells were grown in closed flasks in Eagle's minimum essential medium with Earle's balanced salt solution (EBSS) supplemented with $15 \mathrm{mM}$ HEPES [4-(2-hydroxyethyl)-1-piperazineethanesulfonic acid], $5.3 \mathrm{mM} \mathrm{NaHCO}, 10 \%$ foetal bovine serum (FBS), $4 \mathrm{mM} \mathrm{l-glutamine} \mathrm{and} 50 \mu \mathrm{g} \mathrm{ml}^{-1}$ gentamicin and incubated in air at $20^{\circ} \mathrm{C}$. For virus propagation in tissue culture plates, the same medium was used, except that HEPES was replaced with $16.4 \mathrm{mM}$ Tris-buffer.

Infective material. Kidney tissue was collected from moribund Atlantic salmon parr during an outbreak of IPN in a fish farm in western Norway in July 1994. The tissue was kept frozen $\left(-70^{\circ} \mathrm{C}\right)$ until preparation of a homogenate $(10 \%, \mathrm{w} / \mathrm{v}$, in EBSS) and inoculation onto BF-2-cells. Cell culture fluid obtained after a single passage was used as the infective material. Virus titre (50\% tissue culture infective dose, TCID $_{50}$, see below) was $10^{7} \mathrm{ml}^{-1}$ supermatant. The IPNV was of serotype $\mathrm{Sp}$, strain N1. Serotyping was performed by Intervet Norbio, A/S according to Christie et al. (1990) using a panel of 3 monoclonal antibodies.

Experiment design. The fry from each species were divided into 2 buckets with 1.5 l aerated water Fish density during exposure was 23 to $28 \mathrm{~g} \mathrm{l}^{-1}$ of water with a temperature of $8^{\circ} \mathrm{C}$. A virus suspension $(1.5 \mathrm{ml})$ was added to 1 bucket with Atlantic salmon and 
Table 1. Number of fry exposed to either infectious pancreatic. necrosis virus (IPNV) or to Earle's balanced salt solution (EBSS) / cumulative mortality $69 \mathrm{~d}$ after challenge. Following exposure the fry were distributed between 8 tanks

\begin{tabular}{|lcccc|}
\hline & \multicolumn{4}{c|}{ Exposure } \\
& IPNV & \multicolumn{2}{c|}{ EBSS } \\
\hline Atlantic salmon & $102 / 78$ & $109 / 89$ & $109 / 7$ & $110 / 16$ \\
Brook trout & $103 / 43$ & $113 / 49$ & $106 / 8$ & $96 / 10$ \\
\hline
\end{tabular}

1 bucket with brook trout, to give a final IPNV concentration in the buckets of $10^{4} \mathrm{TCID}_{50} \mathrm{ml}^{-1}$. For controls, $1.5 \mathrm{ml}$ EBSS were added to each of the 2 remaining buckets with Atlantic salmon and brook trout, respectively. After $5 \mathrm{~h}$, fish were transferred back to the tanks and each group was divided into 2 parallel tanks. The numbers of challenged fry in each tank are shown in Table 1.

Before challenge, 20 fry from each species were killed and frozen at $-70^{\circ} \mathrm{C}$. All dead fish collected during the study (Table 1) were also frozen at $-70^{\circ} \mathrm{C}$. All fry sampled prior to the study and 3 pooled samples of dead fry collected from each tank during the study were selected for virological examinations. Each pooled sample contained 3 to 6 fry. From the 2 control tanks with the lowest mortalities, additional healthy fry collected at the end of the study were also examined so that a total of at least 10 fry from each tank were examined.

Ten fry from each. species collected prior to challenge, and all moribund fish observed during the study, were killed and fixed in $10 \%$ phosphate-buffered formalin for subsequent histological examination.

Virus identification and quantitation. Pooled samples of 3 to 6 fry were examined. The head and tail were removed before homogenisation $(10 \%, w / v)$ in cell culture medium with Tris buffer as described above except that FBS was replaced with $10 \%$ newborn bovine serum. After centrifugation, the homogenate was added to BF-2 cells in 24 -well cell culture plates and the remaining homogenate was frozen at $-70^{\circ} \mathrm{C}$. Cells were exposed to a final tissue concentration (w/v) of 1 and $0.1 \%$, respectively. Cell culture medium was passaged to new cell cultures after $1 \mathrm{wk}$ of incubation at $15^{\circ} \mathrm{C}$. One week thereafter, medium from cultures exhibiting cytopathic effect was added to BF-2 cells seeded in 96-well plates for identification of IPNV by indirect immunofluorescence using the monoclonal antibody anti-VP3 (C12, Intervet, Norbio A/S) as the primary antibody and fluorescein isothiocyanate (FITC)-conjugated goat anti-mouse immunoglobulin as the secondary antibody. Serotyping was performed by Intervet Norbio $\mathrm{A} / \mathrm{S}$ as described above.

The TCID To $_{50}$ of IPNV-positive samples was determined by end-point dilution (Reed \& Muench 1938) of fry homogenate on BF-2 cells in 96-well microtitre plates using 6 wells per dilution.

Histology and immunohistochemistry. All samples of formalin-fixed fry were processed and embedded in paraffin wax according to standard routines. Sagittal sections (4 to $6 \mathrm{\mu m}$ ) of whole fry were stained with haematoxylin and eosin (HE) and examined by light microscopy. All sections of fry collected prior to challenge, a representative selection of sections from fry in challenged tanks (41 of 118 sections) and all sections of fry from control tanks were also examined immunohistochemically for the identification of IPNV (Evensen \& Rimstad 1990, Taksdal et al. 1995).

Statistics. Moribund fish that were collected for examination were recorded as dead and included when calculating cumulative mortality. Final cumulative mortalities in parallel tanks with challenged fish were combined and compared with the corresponding mortality in tanks with non-challenged fish using a chisquared test (Martin et al. 1987). To examine the variation in cumulative mortality between tanks, all pairs of parallel tanks were compared, using the same test.

\section{RESULTS}

\section{Mortality}

Mortality of Atlantic salmon challenged with IPNV was observed $14 \mathrm{~d}$ after challenge in both parallel tanks (Fig 1). Thereafter, only a few fish died until $30 \mathrm{~d}$ after challenge when the mortality increased to approximately $70 \%$ over a period of $20 \mathrm{~d}$. At the end of the experiment ( $69 \mathrm{~d}$ after challenge), the cumulative mortality of Atlantic salmon reached 76 and $82 \%$ in the challenged groups compared with 6 and $15 \%$ in the control groups.

In brook trout, mortality of fish challenged with IPNV appeared 5 and $7 \mathrm{~d}$ after challenge in the 2 parallel tanks, respectively (Fig. 2). Cumulative mortality increased steadily with time and reached 42 and $43 \%$ at $69 \mathrm{~d}$ after challenge. The corresponding values of the control fish were 8 and $10 \%$

The final cumulative mortality of IPNV-challenged fish was significantly higher than that of fish in the control tanks for both A.tlantic salmon $(p<0.01)$ and for brook trout $(p<0.01)$. The cumulative mortality in parallel tanks was not significantly different.

\section{Clinical and histopathological findings}

Challenged fish showed darkening of the body and change in swimming behaviour, including circling movements. Abdominal swelling was also seen, 


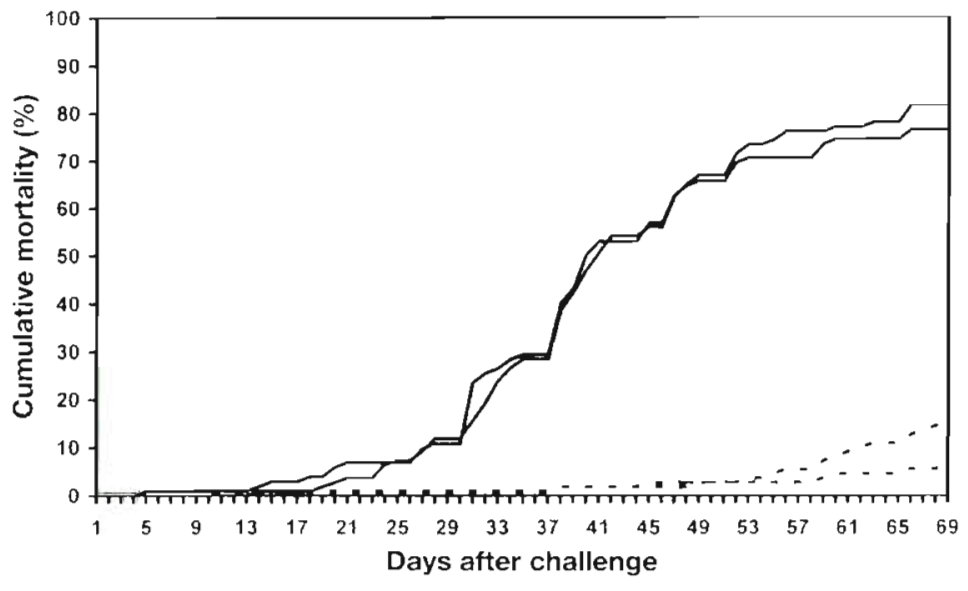

Fig. 1. Salmo salar. Cumulative mortality of Atlantic salmon in 2 parallel tanks with fry challenged with IPNV (solid lines) and 2 parallel tanks with fry exposed to EBSS (dashed lines)

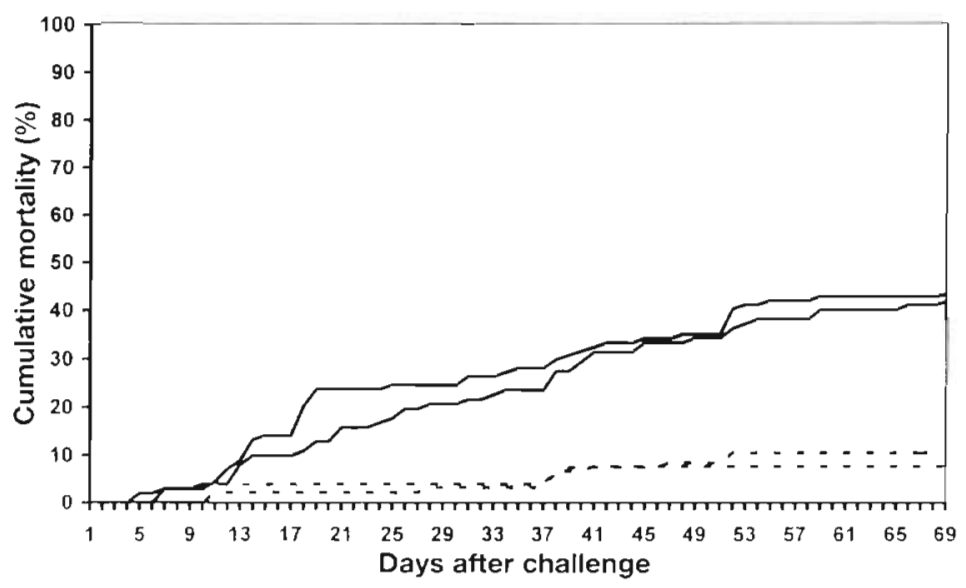

Fig. 2. Salveinus frontinalis. Cumulative mortality of brook trout in 2 parallel tanks with fry challenged with IPNV (solid lines) and 2 parallel tanks with fry exposed to EBSS (dashed lines)

although this clinical sign was most frequently observed in Atlantic salmon. Late in the study, some moribund, challenged fry became dark, lean and faced the bottom of the tank, giving them a vertical position in the water

In Atlantic salmon, the first moribund, challenged fish were collected from each of the parallel tanks $14 \mathrm{~d}$ after challenge (Fig 1). In brook trout, the first moribund, challenged fish were observed 10 and $12 \mathrm{~d}$ after challenge and both these fish were collected (Fig 2). Histological examination of HE-stained sections of these 4 fry and of a majority of sections of sampled moribund, challenged fry collected over the whole study showed hepatic degeneration and/or necrosis and/or exocrine pancreatic necrosis. Immunohistochemical examination of a majority of the selected sec- tions from the challenged fry groups, including the first moribund fry observed in each tank, showed intense positive staining of pancreatic and/or liver lesions. Occasionally, reactivity for IPNV was also shown in the myocardium and endocardium and in small foci in the renal interstitium. In samples from challenged fish, only 2 sections of Atlantic salmon collected 49 and 66 d after challenge and 1 section of brook trout fry collected $69 \mathrm{~d}$ after challenge were negative after immunohistochemical examinations.

No histopathological changes were found in the liver and pancreatic tissue from fry collected before challenge or from moribund fish collected from the control tanks. Immunohistochemical examination of these sections also gave negative results. Intraabdominal remnants of yolk were seen in a majority of sections of Atlantic salmon until $3.5 \mathrm{wk}$ post-challenge. Such remnants were rarely found in brook trout.

\section{Virus isolation}

IPNV Sp serotype, N1 strain was re-isolated from dead fish collected from all challenged groups. Virus titres varied between $3 \times 10^{3}$ and $2 \times 10^{4} \mathrm{TClD}_{50} \mathrm{~g}^{-1}$. No virus was isolated from fry prior to challenge or from the control groups.

\section{DISCUSSION}

In this study, clinical IPN was experimentally induced in Atlantic salmon fry. The diagnosis of IPN was based on histopathological criteria, on immunohistochemical demonstration of IPNV in the lesions and on isolation of virus from pooled samples of whole fry. The histopathological lesions demonstrated in sections from moribund fry were in accordance with the lesions found in field cases. Necrosis of exocrine pancreatic and liver tissue was the most prominent pathological change in moribund fry. Heart and renal interstitial tissue were probably also involved during pathogenesis of the disease in young fry, as indicated by the (intermittent) reactivity for IPNV in these tissues

The virus titres obtained from dead fish from the challenged groups were lower than expected. However, all tissue samples had been frozen before examination and subsequently all fry homogenates had been frozen once more before titration. This may have con- 
tributed to the decreased virus titres. In addition, the whole body of the fry, except for head and tail, was used as the source tissue for virological examination. which may represent a dilution of the virus titre compared with the actual titre in kidney tissue.

In Atlantic salmon, mortality was delayed and initially lower than in brook trout. Sections from the 2 first moribund fry collected 14 d after challenge from each of the parallel tanks with IPNV-challenged Atlantic salmon showed typical lesions and positive immunohistochemical staining. This early demonstration of virus indicates that propagation of virus took place in fry prior to the main outbreak of the disease, which occurred over Days 30 to 55 post-infection. IPNV shed into the water from early infected fry was probably an important source of virus for the main outbreak of IPN.

In brook trout, the cumulative mortalities reached 42 and $43 \%$ in challenged groups. This level is close to the mortality recorded by Frantsi \& Savan (1971) in 4 mo old brook trout challenged with a field isolate of IPNV at $10^{\circ} \mathrm{C}$.

The brook trout in this study seemed less susceptible to IPNV than Atlantic salmon. This difference in susceptibility could be due to species or strain difference or to age. The histological examinations indicate that the brook trout fry were more mature than the Atlantic salmon fry. In sections of brook trout, intra-abdominal remnants of yolk were rarely seen while a majority of the sections from Atlantic salmon up until 3.5 wk post-challenge showed intra-abdominal remnants of yolk. The age of the Atlantic salmon and brook trout, respectively, stated as time post-hatch ( 13 and 15 wk), and days $x$ degrees (410 and 560), supports this histological observation. Experimental studies with brook trout and rainbow trout have shown that the susceptibility to IPNV decreases with the age of the fish (Frantsi \& Savan 1971 , Dorson \& Torchy 1981, McAllister \& Owens 1986).

In experimental studies, only very young fish have been shown to develop clinical IPN, probably because the immune system has not been sufficiently developed. Salmonid fry have been shown to possess an efficient phagocytic system as early as $4 \mathrm{~d}$ post-hatch at $14^{\circ} \mathrm{C}$ (Tatner \& Manning 1985). Specific humoral and cellular immunity develops coincident with the onset of feeding (Ellis 1977, Tatner \& Manning 1983, Nagae et al. 1993). Protective immunity against IPNV has been induced in fry as early as 2 to $3 \mathrm{wk}$ post-hatch at mean weights of 49 and $60 \mathrm{mg}$ (Bootland et al. 1990). However, a maximum protective immunity against Vibrio anguillarum and Yersinia ruckeri bacterins occurred between 1.0 and $2.5 \mathrm{~g}$ (Johnsen et al. 1982). As both species used in this study had been feeding for 2.5 wk prior to challenge, the fish were presumably immunocompetent although below their maximum immunological capacity.
A comparison of previously published studies that have undertaken the experimental challenge of salmonids with IPNV, including those studies that failed, would be a logical approach to determine the best challenge model. However, the results of these previous studies are dependent on the condition of the experimental fish (species, strain, age/maturity, earlier exposures to infective agents), the infective agent (serotype, strain, degree of attenuation during cell culture, concentration), the infection method (bath, injection), and the environment (temperature, water quality, feeding and stressful situations). These factors all interact and make comparisons of the various studies difficult.

We assume that the use of the first passage of IPNV in cell culture as the infective material in this study was essential for the present successful results. Dorson et al. (1975) showed that a virulent Sp serotype of IPNV changed into a non-pathogenic variant after 7 passages in RTG-2 cells. McAllister \& Owens (1986) obtained similar results using CHSE-214 cells. It may also be significant that the challenge virus was isolated from fish with clinical IPN.

The experimental fish used in the present study originated from feral brood fish, which usually have a far lower prevalence of IPNV than farmed fish in Norway (based on examinations at the Central Veterinary Laboratory conducted since 1990). The negative results of virological examination of 20 fish from each species prior to challenge, and the negative results of examinations of the control fish, which included all dead fry from control tanks sampled during the study, indicate that the fish were not carriers of IPNV. The possibility of the presence of healthy carrier fish prior to challenge can not, however, be totally excluded. Nevertheless, IPN was induced in all fry groups challenged with IPNV in contrast to the absence of the disease in all non-challenged fry groups.

This study shows that the experimental induction of clinical IPN in Atlantic salmon fry is possible. The present protocol has subsequently been used in 2 additional challenge experiments with positive results (authors' unpubl. data). As IPN causes large economic losses in Norwegian fish farming, it is important to develop optimal and reproducible experimental models for further studies of pathogenesis and immunization, and for the selection of resistant strains of salmon.

Acknowledgements. This study was supported by the Norwegian Research Council (NFR). Thanks to Freddy Jensen for sampling Atlantic salmon parr during an outbreak of IPN and to Rune Eikeland and Kai Olav Tveit for providing the Atlantic salmon fry and brook trout fry, respectively. The antigenic analysis of IPNV was kindly performed by Karen Elina Christie, Intervet Norbio A/S, Thormehlensgt. 55, N-5008 Bergen, Norway. The technical assistance of Inger Austrheim is greatly appreciated. 


\section{LITERATURE CITED}

Ahne W (1980) Vorkommen des Virus der infektiosen Pankreasnekrose der Forellen (IPN) bei verschiedenen Fischarten. Berl Münch Tierärzol Wochenschr 93:14-16

Biering E, Nilsen F, Rodseth OM, Glette J (1994) Susceptibility of Atlantic halibut Hippoglossus hippoglossus to infectious pancreatic necrosis virus. Dis Aquat Org 20:183-190

Bootland LM, Dobos P, Stevenson RMW (1986) Experimental induction of the carrier state in yearling brook trout: a model challenge protocol for IPNV immunisation. Vet Immunol Immunopathol 12:365-372

Bootland LM, Dobos P, Stevenson RMW (1990) Fry age and size effects on immersion immunization of brook trout, Salvelinus fontinalis Mitchell, against infectious pancreatic necrosis virus. J Fish Dis 13:113-125

Castric J, Baudin-Laurencin F, Coustans MF, Auffret M (1987) Isolation of infectious pancreatic necrosis virus $\mathrm{Ab}$ serotype, from an epizootic in farmed turbot, Scophthalmus maximus. Aquaculture 67:117-126

Christie KE, Ness S, Djupvik HO (1990) Infectious pancreatic necrosis virus in Norway: partial serotyping by monoclonal antibodies. J Fish Dis 13:323-327

Dorson M (1982) Nécrose pancréatique infectieuse des salmonidés: état des connaissances concernant les virus et les possibilités de lutte contre la maladie. Bull Fr Piscic 285:195-209

Dorson $M$, deKinkelin P, Torchy C (1975) Virus de la nécrose pancréatique infectieuse: acquisition de la sensibilité au facteur neutralisant du sérum de truite après passages successifs en culture cellulaire. CR Acad Sci Sér D 281: $1435-1438$

Dorson $M$, dekinkelin $P$, Torchy $C$ (1992) Interferon synthesis in rainbow trout fry following infection with infectious pancreatic necrosis virus. Fish \& Shellfish Immunol 2:311-313

Dorson $M$. Torchy $C$ (1981) The influence of fish age and water temperature on mortalities of rainbow trout Salmo gairdneri Richardson, caused by a European strain of infectious pancreatic necrosis virus. $J$ Fish Dis 4:213-221

Elazhary MASY, Lagacé A, Cousineau G, Roy RS (1976) Outbreak of infectious pancreatic necrosis in yearling brook trout. J Fish Res Bd Can 33:2621-2625

Ellis AE (1977) Ontogeny of the immune response in Salmo salar. Histogenesis of the lymphoid organs and appearance of membrane immunoglobulin and mixed leucocyte reactivity. Symp Dev Immunobiol 225-231

Evensen $\varnothing$. Rimstad E (1990) Immunohistochemical identification of infectious pancreatic necrosıs virus in paraffinembedded tissues of Atlantic salmon (Salmo salar). J Vet Diagn Invest 2:288-293

Frantsi C. Savan M (1971) Infectious pancreatic necrosis virus - temperature and age factors in mortality. $\mathrm{J}$ Wildl Dis 7:249-255

Hastein T, Krogsrud J (1976) Infectious pancreatic necrosis First isolation of virus from fish in Norway. Acta Vet Scand 17:109-111

Jarp J, Gjevre AG, Olsen AB, Bruheim T (1995) Risk factors for furunculosis, infectious pancreatic necrosis and mortality in post-smolts of Atlantic salmon, Salmo salar L. J Fish Dis 18:67-78

Johnson KA, Flym JK, Amend DF (1982) Onset of immunity in salmonid fry vaccinated by direct immersion in Vibrio anguillarum and Yersinia rucken bacterins. J Fish Dis 5: $197-205$

Krogsrud J, Hàstein T, Ronnungen K (1989) Infectious pancreatic necrosis virus in Norwegian fish farms. In. Ahne W, Kurstak E (eds) Viruses of lower vertebrates. Springer, Berlin, p 284-291
Martin SW, Meek AH, Willeberg P (1987) Veterinary epidemiology lowa State University Press, Ames

McAllister PE. Owens WJ (1986) Infectious pancreatic necrosis virus: protocol for a standard challenge to brook trout. Trans Am Fish Soc 115:466-470

McAllister PE, Owens WJ (1995) Assessment of the virulence of fish and molluscan isolates of infectious pancreatic necrosis virus for salmonid fish by challenge of brook trout, Salvelinus fontinalis (Mitchill). J Fish Dis 18:97-103

McKnight IJ, Roberts RJ (1976) The pathology of infectious pancreatic necrosis. I. The sequential histopathology of the naturally occurring condition. Br Vet J 132:76-85

Nagae M, Fuda H, Hara A, Kawamura H, Yamauchi K (1993) Changes in serum immunoglobulin $M$ (IgM) concentrations during early development of chum salmon (Oncorhynchus keta) as determined by sensitive ELISA technique. Comp Biochem Physiol 106A(1):69-74

Reed RJ, Muench $\mathrm{H}$ (1938) A simple method of estimating fifty per cent endpoints. Am J Hyg 27:493-497

Sano T (1976) Viral diseases of cultured fishes in Japan. Fish Pathol 10:221-226

Shankar KM, Yamamoto T (1994) Prevalence and pathogenicity of infectious pancreatic necrosis virus (IPNV) associated with feral lake trout, Salvelinus namaycush (Walbaum). J Fish Dis 17:461-470

Silim A, Elazhary MASY, Lagacé A (1982) Susceptibility of trouts of different species and origins to various isolates of infectious pancreatic necrosis virus. Can J Fish Aquat Sci $39: 1580-1584$

Smail DA, Grierson RJ, Munro ALS (1986) Infectious pancreatic necrosis (IPN) virus in Atlantic salmon: virulence studies and sub-clinical effects with respect to growth, smolting performance and condition. Int Counc Explor Sea ICES-CM/1986/F:8

Sorimachi M, Hara T. (1985) Characteristics and pathogenicity of a virus isolated from yellowtail fingerlings showing ascites. Fish Pathol 19:231-238

State Veterinary Laboratory, Trondheim, Norway (1994) Utbredelse og okonomisk betydning av sykdommen IPN i Norge. State Veterinary Laboratory, Trondheim (in Norwegian)

Swanson RN, Carlisle JC, Gillespie JH (1982) Pathogenesis of infectious pancreatic necrosis virus infection in brook trout, Salvelinus fontinalis (Mitchill), following intraperitoneal injection. J Fish Dis 5:449-460

Swanson RN, Gillespie JH (1979) Pathogenesis of infectious pancreatic necrosis in Atlantic salmon (Salmo salar). J Fish Res Bd Can 36:587-591

Swanson RN, Gillespie JH (1981) An indirect fluorescent antibody test for the rapid detection of infectious pancreatic necrosis virus in tissues. $J$ Fish Dis 4:309-315

Taksdal T, Poppe T, Sivertsen T, Ferguson H W (1995) Low levels of vitamin $E$ in plasma from Atlantic salmon Salmo salar with acute infectious pancreatic necrosis (IPN). Dis Aquat Org 22:33-37

Tatner MF, Manning MJ (1983) The ontogeny of cellular Immunity in the rainbow trout, Salmo gairdneri Richardson, in relation to the stage of development of the lymphoid organs. Dev Comp Immunol 7:69-75

Tatner MF, Manning MJ (1985) The ontogenic development of the reticulo-endothelial system in the rainbow trout, Salmo gairdneri Richardson. J Fish Dis 8:189-195

Wolf K (1988) Fish viruses and fish viral diseases. Cornell University Press, Ithaca

Wolf K, Quimby M (1969) Infectious pancreatic necrosis: clinical and immune response of adult trouts to inoculation with live virus. J Fish Res Bd Can 26:2511-2516 